Indonesian Journal of Nutrition and Dietetics Vol. 7, No. 2, 2019: 37-40
Available online at: http://ejournal.almaata.ac.id/index.php/IJND DOI : http://dx.doi.org/10.21927/ijnd.2019.7(2).37-40

\title{
Total phenol and antioxidant activities of rice bran yoghurt
}

\author{
Olvi Ariyani ${ }^{1}$, Fatma Zuhrotun Nisa², Mulono Apriyanto ${ }^{3}$, Veriani Aprilia ${ }^{1 *}$ \\ ${ }^{1}$ Department of Nutrition, Faculty of Health Sciences, Universitas Alma Ata Yogyakarta, \\ Jalan Brawijaya 99, Tamantirto Yogyakarta, \\ ${ }^{2}$ Department of Nutritition and Health, Universitas Gadjah Mada, Jl. Farmako, Sekip Utara, Yogyakarta 55281 \\ ${ }^{3}$ Department of Food Technology, Indragiri Islam University, \\ Jalan Provinsi Parit 1 Tembilahan Hulu Kabupaten Indragiri Hilir, Riau \\ *Corresponding author: verianiaprilia@almaata.ac.id
}

\begin{abstract}
ABSTRAK
Latar Belakang: Bekatul merupakan salah satu produk pertanian Indonesia yang kaya akan zat bioaktif, terutama senyawa fenolik dan fitokimia. Senyawa fenolik sulit diekstraksi karena seratnya tidak larut air. Salah satu cara untuk mengekstraksinya yaitu dengan fermentasi. Yogurt merupakan salah satu produk fermentasi susu. Adanya penambahan bekatul ke dalam yogurt dapat meningkatkan efek fungsionalnya, tidak hanya efek kesehatan saluran cerna, tetapi juga efek antioksidatifnya.

Tujuan: Untuk mengetahui pengaruh proses fermentasi terhadap aktivitas antioksidan dan total fenol yogurt dengan adanya penambahan bekatul.

Metode: Penelitian ini merupakan penelitian eksperimental menggunakan rancangan acak lengkap. Ada 4 formula yogurt yang berbeda pada jumlah bekatul yang ditambahkan, antara lain: 0\%, 5\%, 10\%, dan $15 \%$. Total fenol dianalisis menggunakan metode Follin-Ciocalteu dan aktivitas antioksidan dianalisis dengan metode DPPH. Data kemudian dianalisis statistika menggunakan one-way ANOVA dan dilanjutkan dengan uji beda nyata Duncan.

Hasil: Penambahan bekatul pada konsentrasi yang lebih tinggi memengaruhi persentase total fenol yang

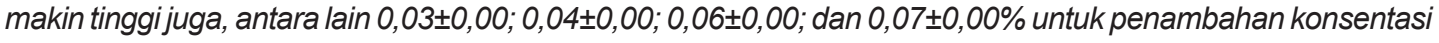

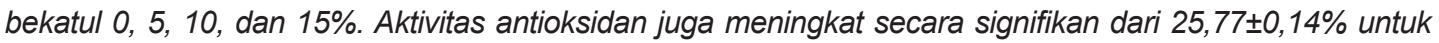

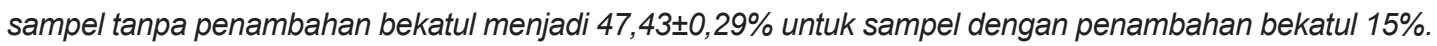
Kesimpulan: Penambahan bekatul memiliki efek yang signifikan terhadap peningkatan total fenol dan aktivitas antioksidan yogurt.
\end{abstract}

KATA KUNCI: bekatul, yogurt, aktivitas antioksidan, total phenol

\begin{abstract}
Background: Rice bran is one of Indonesia agricultural product that is high in bioactives, especially phenolic and phytochemical compounds. Phenolic compunds are difficult to extract because the fiber can not solute in water. An alternative way to extract is by fermentation. Yogurt is one of dairy fermentation product. The addition of rice bran into the yogurt will improve its functional effect, not only provides the gastrointestinal health effects but also antioxidant activity.

Objectives: To investigate the influence of fermentation process on the antioxidant activity and total phenol of yogurt with the addition of rice bran.

Methods: This was an experimental study using completely randomized design. There were 4 formulation of yogurts with different amount of rice bran, i.e. $0 \%, 5 \%, 10 \%$, and 15\%. Total phenol was measured by FollinCiocalteu methods and the antioxidant activity was analyzed by DPPH. Data were analyzed statistically by one-way ANOVA and continued to Duncan's multiple range test.

Results: The addition of rice bran in higher concentration showed higher percentage of total phenol, those were $0.03 \pm 0.00 ; 0.04 \pm 0.00 ; 0.06 \pm 0.00$; and $0.07 \pm 0.00$ respectively for the addition of $0,5,10$, and $15 \%$ of rice bran. The antioxidant activities were also increased significantly from $25.77 \pm 0.14 \%$ for sample without rice bran to $47.43 \pm 0.29 \%$ for sample with the addition of $15 \%$ rice bran.

Conclusions: The addition of rice bran gave the significant effect on total phenol and antioxidant activity of yogurt.
\end{abstract}

KEYWORDS: rice bran, yogurt, antioxidant activity, total phenol 


\section{INTRODUCTION}

The availability of rice bran in Indonesia is abundant. The data showed that in 2009 , total rice production was about 64.3 million tons/year and it increased to 66.8 million tons/year in 2010. Along with the increased in production of rice, the bran could also reached 5.3-6.7 million tons/year (1). In 2011, the rice production reached 65.76 million tons/year. If the process of rice milling produced $8 \%$ of bran, the bran could reach 5.2 million tons (2).

Rice bran is a rice milling by-product that is usually discarded and not consumed by human. It has been used as animal feed. The previous study was proved that rice bran has functional activity such as reducing the incidence of diabetes mellitus (3). Because of the good effect to the body and health, rice bran has been used as the human food. However, the uses are still limited. It needs more exploration about diversification, modification, or technology for widely use of the rice bran (4).

Rice bran has potential antioxidant activity, especially from its phenolic and phytochemical compounds such as tocopherol, tocotrienol, oryzanol and other antioxidant compounds (5). Most of them could be found in outer layer of rice bran. Among them, more than $1 \%$ of phenolic antioxidants was covalently binded with insoluble fibers so their bioavailability become low (6). The hydrolization that was done by microbes through fermentation may assist the release of phenolic compounds (7).

Yogurt is one of favors milk product fermented by lactic acid bacteria (8). It has good health effects such as preventing diarrhea and boosting the immune system. Enough consume of probiotic drinks may resist to gastric acid, bile salts and inhibit the growth of pathogenic bacteria in the body (2). The addition of antioxidant compounds that may be sourced from rice bran to the yogurt is an alternative way to improve the health function of the product. It may also give the new flavors of yogurt, beside fruit variants that usually used in commercial product. It needs more study to prove the addition of health function, especially antioxidant activity of yogurt added with rice bran. This study aimed to investigate the influence of fermentation process on total phenol and antioxidant activity of yogurt with the addition of rice bran.

\section{MATERIALS AND METHODS}

Rice bran was obtained from one of the milling factory in Bantul, Yogyakarta, Indonesia. The bran was then brought to the laboratory for sieving with the mesh size of 60 , and sterilized before added to the yogurt.

Yogurt was prepared by mixing skim milk, UHT milk, and rice bran. They were then stirred and pasteurized at $80-90^{\circ} \mathrm{C}$ for 10 minutes. Lactobacillus bulgaricus and Streptococcus thermophillus were inoculated into the mix substance and incubated for 18 hours at $37^{\circ} \mathrm{C}$.

The samples were devided into 4 formulations of yogurt with different amount of rice bran, i.e. $0 \%$, $5 \%, 10 \%$, and $15 \%$. Rice bran was substituted to UHT milk. Total phenol was measured by FollinCiocalteu methods and the antioxidant activity was analyzed by DPPH (9). Data were then analyzed statistically by one-way ANOVA and continued to Duncan's multiple range test.

\section{RESULTS AND DISCUSSIONS}

\section{Total phenolic compound in rice bran yogurt}

Table 1 showed the total phenolic compound in yogurt with the addition of rice bran.

Table 1. Total phenolic compound in rice bran yogurt

\begin{tabular}{cc}
\hline $\begin{array}{c}\text { Amount of rice bran } \\
\text { added (\%) }\end{array}$ & $\begin{array}{c}\text { Total phenolic } \\
\text { compound (\%) }\end{array}$ \\
\hline 0 & $0.03 \pm 0.00^{\mathrm{a}}$ \\
5 & $0.04 \pm 0.00^{\mathrm{b}}$ \\
10 & $0.06 \pm 0.00^{\mathrm{c}}$ \\
15 & $0.07 \pm 0.00^{\mathrm{d}}$ \\
\hline
\end{tabular}

*Different superscript in the same coloumn showed significantly different $(p<0.05)$

Table 1 showed that native yogurt $(0 \%$ substituted) had the lowest total phenol, but the substitution of $15 \%$ rice bran had the highest total phenol. The statitical analysis proved that substitution of milk with rice bran affected phenol content in the sample $(p<0,05)$. The higher the addition of rice bran, the higher the phenol detected in the samples.

Rice bran is popular for its high natural antioxidant components, such as tocopherol, tocotrienol, oryzanol, phenolic compound, and anthocyanin $(10,11)$. Based 
on the data, it can be known that native yogurt had $0.03 \%$ of total phenol. In the rice bran, there was also $0.22 \%$ of total phenol. The addition of rice bran that was high in total phenol was contributed on the higher value of total phenol than that was in the native. This result is similar with previous study that found the increase of phenol content after the addition of rice bran to the fermented milk with $L$. plantarum and $L$. acidophilus as starter (4).

\section{Antioxidant activity}

Based on Table 2, the antioxidant activity of yogurt was higher when rice bran was added. The yogurt formulation with the substitution of $15 \%$ of rice bran had the highest antioxidant activity, while $0 \%$ had the lowest antioxidant activity. The statistical analysis showed that the substitution of rice bran significantly affected the antioxidant activity $(p<0.05)$. The higher the addition of bran flour, the higher the phenolic compound is released, therefore the higher the antioxidant activity is produced.

Table 2. Antioxidant activity of rice bran yogurt

\begin{tabular}{cc}
\hline $\begin{array}{c}\text { Amount of rice bran } \\
\text { added (\%) }\end{array}$ & Antioxidant activity (\%) \\
\hline 0 & $25.77 \pm 0.14^{\mathrm{a}}$ \\
5 & $34.09 \pm 0.29^{\mathrm{b}}$ \\
10 & $39.73 \pm 0.14^{\mathrm{c}}$ \\
15 & $47.43 \pm 0.29^{\mathrm{d}}$ \\
\hline
\end{tabular}

*Different superscript in the same coloumn showed significantly different $(p<0.05)$

Rice bran is rich in antioxidant compound, especially total phenol. Their antioxidant activity were related to the molecular structure, the presence and number of hydroxyl group, and double bond conjugation and resonance effect (12). Rice bran had also ferulic acid yielded from hydrolization of fiber during fermentation. This compound may role as antioxidant $(13,14)$.

As explained above, the native yogurt has total phenol that may be potential as antioxidant. Its antioxidant activity may be improved with the presence of small peptides as bioactive peptide from the proteolytic activity of microbes during milk fermentation (15).

\section{CONCLUSIONS AND RECOMMENDATIONS}

Rice bran has been used as food that is high in total phenol. The addition of rice bran to the yogurt has significantly effect on the total phenol and antioxidant activity, especially in scavenging of free radicals. However, it still needs more study about other application of rice bran in foods and also more exploration about it functional activity, especially to the human health.

\section{REFERENCES}

1. Gilliand. Bacteria Starter Culture For Food. New York: CRC Press Inc.; 1986.

2. Harjanti SW. Pembuatan Yoghurt Kacang Merah (Phaseolus Vulgaris L) Dengan Penambahan Ekstrak Bunga Rosela (Hibiscus Sabdariffa L) Sebagai Pewarna Alami. Universitas Muhammadiyah Surakarta Surakarta; 2013.

3. Chen dan Bergman. 2005. A Rapid Procedure for Analysing Rice Bran Tocopherol, Tocotrienol and Gamma Oryzanol Contents. Journal of Food Composition and Analysis 18 : 139-151.

4. Hartati, S., Yustinus, M., Suparmo, U.,Umar, S. 2015. Komposisi Kimia Serta Aktivitas Antioksidan Ekstrak Hidrofilik Bekatul Beberapa Varietas Padi. Jurnal Agritech. Vol 35 no 1.

5. Shen, T. 2009. Function of Rice Bran. Journal of Food Composition and Analysis 19 : 120-130.

6. Zubaidah E dan Kurniawan Y. 2010. Pengaruh Konsentrasi Ragi Roti (Dry Instant Yeast) terhadap Aktivitas Antioksidan dan Antibakteri Cuka Salak (Salacca zalacca) dan Cuka Apel (Malus sylvestris). [Skripsi]. Malang : Jurusan Teknologi Hasil Pertanian.

7. Fakultas Teknologi Pertanian. Universitas Brawijaya.

8. Zubaidah, E. dan Wulandari. 2010. Pengaruh Pemberian Cuka Apel dan Cuka Salak terhadap Kadar Glukosa Darah Tikus Wistar yang Diberi Diet Tinggi Gula. Malang : Fakultas Teknologi Pertanian-Brawijaya.

9. Sompong, R., Siebenhandl-Ehn, S., Linsberger, MG., Berghofer, E. 2011. Physicochemical and antioxidative properties of red and black rice 
varieties from Thailand, China and Sri Lanka. Food Chemistry 124: 132-140.

10. Koswara. 2009. Teknologi Pembuatan Yogurt. Tersedia dalam ://http.ebook pangan.com/ diunduh pada hari Kamis, 20 Oktober 2016 pukul 18.10 WIB.

11. Godber, J., Xu, Z. Hegsted, M, .,Walker, T. 2002 : Rice and Rice Bran Oil in Function Food Development. Lousiana Agriculture. Vol 45, 9-10.

12. Bendary, E., Francis, R.R., Ali H.M.G., Sarwat, M.I., Hady, E., 2013. Antioxidant and structureactivity relationship (SARs) of some phenolic and anilines compounds. Annals of agricultural science, 58(2), 173-181.
13. Baublis, A., J. 2000. Potential of WheatBased breakfast Cereals as Source of Dietary Antioxidants. Massachusetts :The American College of Nutrition.

14. Beghofer, E., Grzeskowiak, B., Mundigler, N., Sentall, W., Walcak, J. 1998. Antioxidative Properties Og Faba Bean, Soybean and Oat Tempeh. International Journal Of Food Science and Nutrition $49: 45-54$.

15. Virtanen, T., Pihlanto, A., Akkanen, S., Korhonen, H. 2006. Development Of Antioxidant Activity In Milk Whey During Fermentation With Lactic Acid Bacteria. Biotecnology adn Food Research MTT Agrifood Research Finland : Finland. 